\title{
Analysis of Transforming Security Through the Water Resources and Affiliated Conflicts Between 2000 and 2019: Case of Iraq,
} Syria and Turkey

\author{
2000-2019 Yılları Arasında Su Güvenliği ve Çatsşmalar Üzerinden Değişen Güvenliğin \\ Analizi: Irak, Suriye ve Türkiye Örnekleri
}

\author{
Murat Aslan' ${ }^{\oplus}$, Cumali Özbek ${ }^{2} \odot$
}

\begin{abstract}
The aim of this study is to analyze the changing nature of water security and affiliated conflicts within the scope of security conceptualization at individual and state levels between the years 2000-2019. It was set out that water conflicts and water insecurity in Iraq, Syria and Turkey in the 20-year period after 2000 were caused by attacks to water resources and infrastructure at micro and mezzo levels, other than natural disasters such as climate change and reduced water resources. This research focuses on the water conflicts that have arisen in recent years, with some exceptions, not between states but by groups operating at regional levels. It has also been observed in recent years that terrorisminduced attacks have focused on waterways and threatens water security. The study focused on the conflicts occurring in Iraq, Syria and Turkey and the causes of these conflicts within the framework of comparative analysis method.
\end{abstract}

\section{Keywords}

Water Security, Water Conflicts, Iraq, Syria, Turkey

Öz

Bu çalışmanın amacı; 2000-2019 yılları arasında su güvenliği ve su çatı̧malarının birey ve devlet güvenliği kapsamında değişen niteliğinin analizini yapmaktır. Bu çalışmada; iklim değişimi ve azalan su kaynakları dışında; 2000 sonrası 20 yıllık dönemde Irak, Suriye ve Türkiye'deki su kaynaklarına ve altyapısına yapılan saldırıları konu edinmektedir. Bu kapsamda su güvensizliğinin mikro ve mezo seviyede su kaynaklarını ve altyapısını hedef alan saldırılardan kaynaklandığı ortaya konmuştur. Su çatışmaları, son yıllarda, bazı istisnalar hariç, devletler arasında değil bölgesel nitelikte faaliyet gösteren gruplar tarafindan yürütülmektedir. Bu çerçevede son yıllarda terörizm kaynaklı saldırıların su yolları üzerine yoğunlaştığı ve su güvenliğini tehdit ettiği gözlemlenmiştir. Çalışma; Irak, Suriye ve Türkiye'de meydana gelen su odaklı çatş̧malara ve bu çatışmaların nedenlerine odaklanarak karşılaştırmalı analiz yöntemi çerçevesinde incelenmiştir.

\section{Anahtar Kelimeler}

Su Güvenliği, Su Çatşmaları, Irak, Suriye, Türkiye

1 Corresponding Author: Murat Aslan (Asst. Prof. Dr.), Hasan Kalyoncu University, Faculty of Economics, Administrative \& Social Sciences, Department of Political Science and International Relations, Gaziantep, Turkey. E-mail: murat.aslan@hku. edu.tr ORCID: 0000-0002-5128-1020

2 Cumali Özbek (Doctoral Student), Hasan Kalyoncu University, Social Sciences Institute, Gaziantep, Turkey. E-mail: cumali. ozbek@yahoo.com ORCID: 0000-0003-0587-3751

To cite this article: Aslan, M., \& Ozbek, C. (2021). Analysis of Transforming Security Through the Water Resources and Affiliated Conflicts Between 2000 and 2019: Case of Iraq, Syria and Turkey. SiYASAL: Journal of Political Sciences, 30(1), 109-127. http://doi.org/10.26650/siyasal.2021.30.1.862827 


\section{Introduction}

Water security, specifically in the Middle East, is an issue field in question that has a long historical discourse. The witnessed efforts of varying sorts of actors have focused on the control upon water resources or security of it. Disputes, or conflicts, on dominating water has appeared to ones among the local micro societies with a low profile, or among states as well. But the undertakings to secure (or de-secure) water resources has been taking place in the regional conflicts, which are mostly at the intra-state level. Say another way, struggles to control the water resources has eventuated during the conflicts of sub-state level social-political actors, not among the states themselves. This research will delve the water security and affiliated conflicts with a focus on understanding the reasons and proceedings of them. Eventually the argument of the research is that it will not be suffice understanding water conflicts due to climate change, or water scarcity, but de-securitization by sabotages of, mainly, terror networks per se. In other words, terrorism has become a negative input as asymmetric warfare and proxy wars has infiltrated to the code of conducts in conflicts that reminds the transforming nature of emerging conflicts. To conclude, water resources are themes of the most likely terror threats, not only in Turkey's case, but also during the conflicts in Iraq and Syria, which could lead to a generalization.

\section{Methodology}

The research takes the threats and attacks to water resources and conduits between the years 2000-2019 as the base of the survey. The reason of delimiting a time frame is that this era, with exceptions, witnessed intra state - local conflicts backed by external actors as proxy ones rather than inter-state conventional warfare. For this reason, we have also included the low-intensity conflicts into the codification of conflicts. By that way the escalation tendency in Iraq, Syria and Turkey are scrutinized as far as any act targets water resources or conduits for the purpose of gaining any advantage upon the other party. The investigation has been saturated by a comparison of the previous twenty years with the delimited time frame, which contrasts the years 1980-2000 and 2000-2019.

The research leans on both qualitative and quantitative data analysis methods. In this sense document review and comparative analysis are benefitted while primary and secondary resources are exploited by hermeneutic approach. Tables and graphs are used to support to depict gathered data and simplify the findings. The essential apparatus to gather data is websites of news channels, documents, visual materials and Terrorism Analysis Platform of SETA/STM. The conflicts on water resources and affiliated security issue fields in question are put together in accordance with chronology before concluding a context analysis.

\section{Theoretical Framework}

The research will first cover a theoretical review that takes the security conceptualization as the base of the overall debates on the security of water resources.

\section{On Security}

Security, with its fundamental conceptualization, is to satisfy the preservation of self even though it is a contested concept for David Baldwin in terms of subject, values, degree 
etc. (Baldwin, 1997, s. 5-26) The term essential points out freedom from threat for a safe and stable environment to have regularity of the life continues with no fluctuation. Security becomes a service of state, which is also a collection of humans, to the subjects. Varying interpretations have traces in Sun Tzu's The Art of War, Thucydides' Peloponnesian War, and Clausewitz's On War with a commonality of linking security to the ability of war and power. In comparison to mentioned traditional contextualization; the definition, contextual interpretation and relevant framework of security has been transforming with new aspects. Hence new interpretations have been emerging in relevance with the transforming security contextualization.

Wolfers noted a definitive and wider security description in 1952, as an early attempt, on how its context and limitations could be figured out. He offered a comprehensive definition, away from national security or interest, that includes 'value' to the context of security, reminding its normative aspect. The issue to be pointed out by Wolfer's article is his attempt to widen the nature of security by delineating 'threats against values or presence of fear due to such threat'. (Wolfers, 1952, s. 483-502). Buzan and Ullman's security approach underlines five sectors of security that was rather challenging for then. For them, military, political, societal, economic and societal sectors constitute the fundamental affiliations of security perception. (Buzan, 1983). Ullman includes the quality of life to explain another aspect of security while implying security as affecting, even limiting, policy options. (Ullman, 1983, s. 133). As a result, transformation of security contextualization, in the way to normativism by Wolfers turned out to be a matter of concern in diffusing the quality of life within varying sectors that the security of water resources may be a part of it.

Conceptually, security can precisely be clarified by David Singer's units and level of analysis explanation before linking it to (de)securitization of water resources. 'Unit of analysis' theme is about what to study in terms of its subjects and objects. It indicates the theme to be examined or any existence, usually as 'micro', that differs it with the level of analysis. If the unit is a 'nation', for instance say history, it is history of a nation. Singer usually ignored individual as the unit but relied on state actors or international system to explain international relations. In this sense security can be attributed to varying units of analysis from the security of individual towards international security (Singer, 1971). In the meantime, Singer points out the level of analysis in his famous book $A$ General System Taxonomy for Political Science. He identifies three levels for an analysis of which are not a vertical array. The first is the level of decision makers that signifies individuals (Singer J. D., 1971). Hence security is analyzed at the 'individual's' level addressing transforming security environment and prerequisites. The scholars who study gender and green politics blended security with the concerns on water resources, nutrition, health environment, and many other ones.

Security conceptualization, itself, undergoes 'change' when delved at individual, state or system units of analysis. Security, within its focused analysis level like state actors, converts into sub-level of analysis. In this sense, the analysis that takes state as the essential unit turns out to be fragmented into constituent security compartmentalization, say internal and external varieties. Transforming, and to some extent degrading, structure of politics has brought economy, health, nutrition, environment, and also water resources 
of what the subject matter of this research is. Eventually the analysis on the security of state actor, in correlation with the transformation in the security conceptualization, is in a course of unification in the concerns of individual and state actors. In this context, water security has started to become an issue field in question threatening the individual and state actors. (Sancak, 2013, s. 125). Besides society with differing identities and non-state actors have appeared to be the emerging actors both becoming concerned and also risk factors in perceived security threats, mainly towards water resources.

\section{Water Resources and the Environmental Security}

Water is an indispensable source of life. The limited amount of fresh water on earth made it precise to obtain and preserve due to expanding population, prerequisite of prosperity and consumption of water (The Economist, 2019). Parallel to water's noteworthiness, security and conserve the water resources is in the agenda of all units of analysis, from individual to international society. Besides security of water resources can be correlated with the other constituting 'soft' security sectors such as environmental, health, economy, human, immigration security other than political ones. For this reason, a competition on dominating water resources may diffuse to state functions and societal discourse as if they are not relevant to water's security or vice versa. Such a discourse may escalate conflict on water resources as a natural outcome of competition.

The conflicts upon water resources, if historical discourse is taken, may be attributed to the early ages of human history through which water policy can be established during Babel and Hammurabi Laws 4,000 years ago (O'Hara, 2017, s. 2). Since then, many strategies of controlling water have been developed while wars on dominating water was a commonly observed argument. Hence the conflicts on water resources, and control upon it, may be a fact that can be correlated to population growth and the policies of state actors. Eventually water strategies were designed to manage the resources as mentioned in the book of Michale T. Klare entitled Resource Wars: The New Landscape of Global Conflict, arguing the linkage of conflicts and resources and international system be subjected to what type of strains (Klare, 2005). Besides Klare underlines the prominence of water and the probability of words and conflicts on the water resources as far as their decay. At the mean time Peter H. Gleick argued that these types of wars and conflicts would be among state actors in future (Gleick \& Heberger, 2013). On the other hand, Madeleine Lovelle reminds us, that water conflicts may bring the de-securitization of water and environmental degradation (Lovelle, 2016).

Chart-1 depicts the conflicts and disputes on water between the years $3000 \mathrm{BC}$ and 2019 AD on controlling, managing and security of water, as delineated by the mentioned authors. The conflicts on controlling the water is not a new dilemma a far as historical discourse is scrutinized. This article is not to examine all tough; a brief depiction of the overall conflicts can be reviewed in the Chart. In relevance with the course of organized life, the Middle East and extension to the eastward had become the ground of efforts to dominate water resources through conflicts. It is fact that well-developed water conduits prevented the potential water disputes, mainly during the last century. But development is not homogenous in the globe, or in a region, that water still continues to be an objective or asset to impose a willingness. 


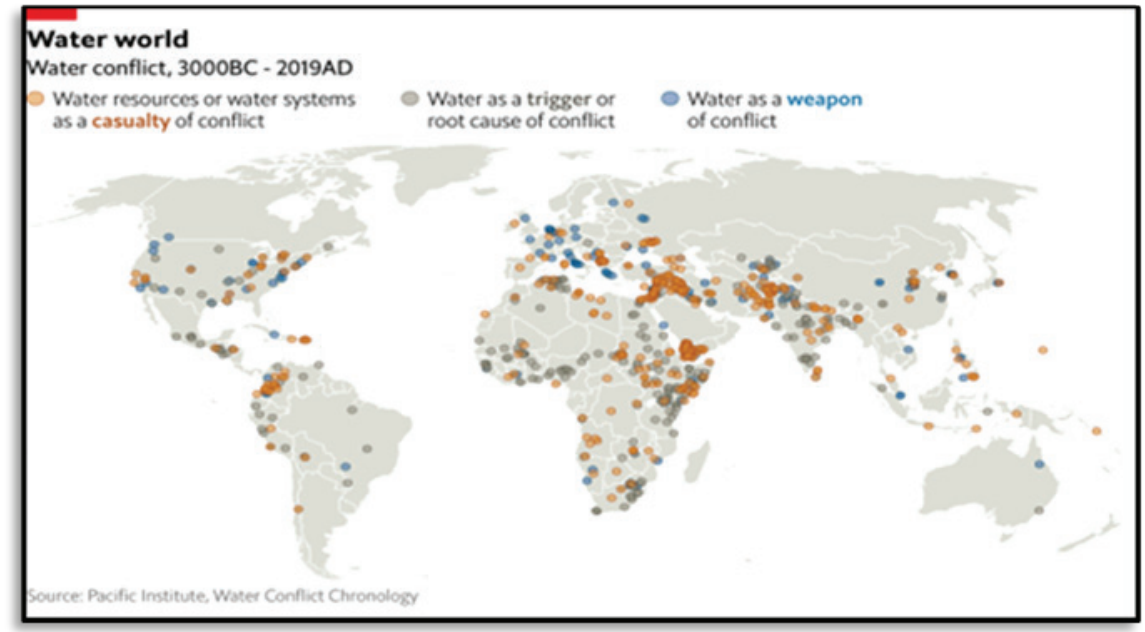

Figure 1. Water Conflicts, 3000 BC - 2019 AD

Source: (Pacific Institute, 2021).

Similar to the abstracted course from the depiction is that current age repeats the cycle on water conflict in the areas that water still not well accessible or single sourced. Besides, the modern interpretation of the water-based competition and confrontation is not only about physical power practices, but also new security perceptions that was claimed by deepened and widened structure of it.

The security paradigm of contemporary International Relations handles the policies on water resources in the frame of environmental conceptualization of security. In this sense the issue fields in question among states are crucial to search, for instance, on the investments to build dams, funding on regional development programs, or climate change codification and regulations. Lester R. Brown of the World watch Institute, as an initial step to point out the new dimension of security, argued in 1977 that "the threats to security may now arise less from the relationship of nation to nation and more from the relationship of man to nature". For Brown, national security need to be redefined due to diminishing natural resources and environmental degradation (Brown, 1977, s. 6). It has been a theme of discussion on how the effective management of water resources and its security can sustainably be aligned. Eventually the security of water, in the frame of environmental degradation, has been a point of concern not only for the individuals but also states due to expanding population and shortage of natural resources which do have strategic prominence. In this sense, Norman Myers delineates in his book Ultimate Security on the transformation of security that national security cannot be maintained by means of military terms or arm procurements but water-rich regions, agriculture, climate, or natural resources to respond to the threats of sustainability and quality of life. Hence public health and vital economic interests are outputs after the preservation of the already possessed resources, say one of which is water (Myers, 1993). In this context the conflicts to dominate or deny water resources at the expense of the threatening actors took place among the local actors at micro and mezzo level rather than inter-state ones, as can be seen in the Figure- 2 . This argument can be argued pending to the fact that conflicts on water resources are in the forms of sabotage by terror networks with a persistent methodology of them. 


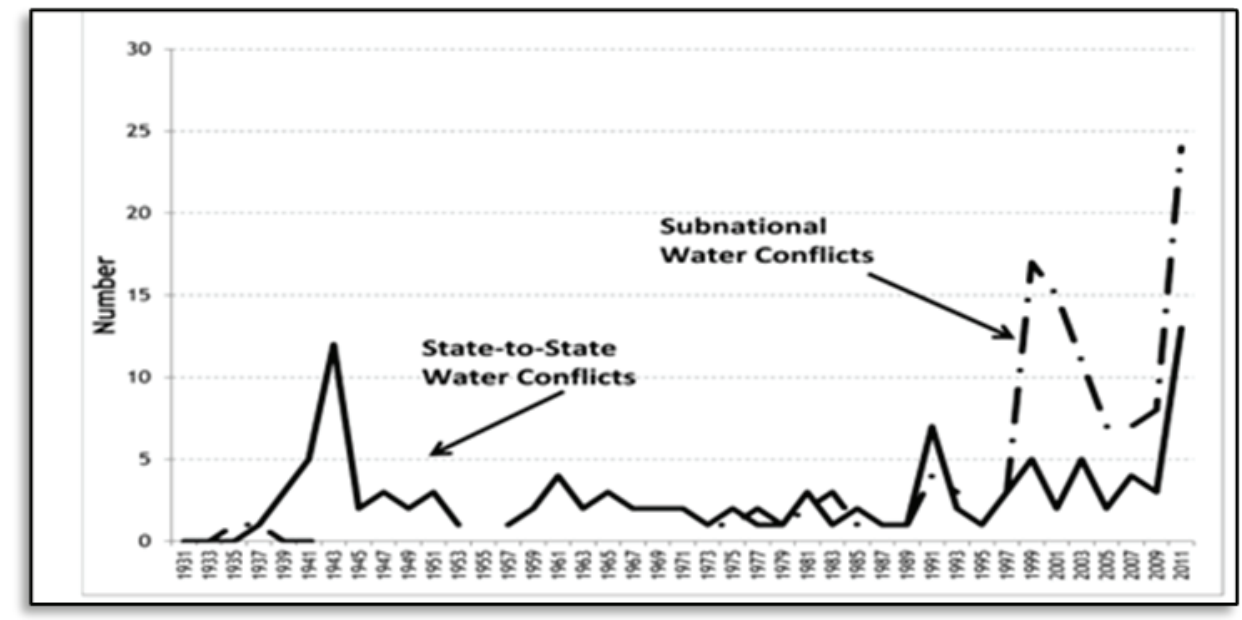

Figure 2. State-to-State and Subnational Conflict Frequency on the Domination of Water Resources between 1931-2011

Source: (Gleick \& Heberger, 2013, p. 162).

In parallel with the above-mentioned argument and increasing tendency of micro mezzo level and local water conflicts, the need to access clean water is ascending to have the societies, and the other living species as well, to survive more profoundly. For this reason, water resources have become both an objective to dominate and, at the meantime, a strategic apparatus to realize the other objectives. Thus, varying scenarios of conflict are being circulated to have access to water that covers the varying levels of individual to state. The expansion desire of Israel towards Golan Heights and Jordan Valley can be an example of such a fact. Meanwhile it may trigger political, economic, or demographic escalations leading to conflicts while local administrative units, industrial complexes, corporations could urge the low and mid-level decision makers to take measures in order to ensure water access. Then risks do exist at 'intra' or 'inter' axis with a motivation of establishing check mechanism upon the resources. Societies are subjected to the effects of mentioned risks surpassing the geo-strategic, military and economic concerns of the state actors.

Once the input of water resources to security perception is concerned, water's security affects all units of analysis, as mentioned above. Military-based security assessments, which may be called as traditional, has turned out to be the one interpretated by multidisciplinary thinking and pursuant to integrated situational analysis. De-securitization, which could flourish from environmental degradation, covers and expands from the individual's concern at the micro, continues across the society and region at the mezzo, and reaches to state / supra state actors at the macro levels of analysis. Specifically, the Middle East has become the theatre that encourages terror networks to target water resources, occupy the water basin, and ultimately control it for zero-sum games against the perceived adversary. As a matter of course, the consequences appear as regular or irregular immigration of the deprived social groupings, droughts due to inefficient water irrigation, and finally military or political quarrels. 
The struggle to dominate the water resources as an exploitation asset causes lowintensity conflicts with a probability leading an international crisis because malevolent practices on water escalates the instability. The minor issue fields in question, emanating from the water disputes, affects many state actors that goes beyond the problem-solving capacity of them. For instance, Ad-Dawlah al-Islamiyah fil-'Iraq wa ash-Sham (DEASH) had demolished the water reservoirs and destroyed the water canals in Iraq and Syria with a consequence of mass immigration towards Turkey at the beginning of the 2010s. This input culminated in the agenda of international community which had first perceived as a regional problem. Meanwhile, terrorism has become the essential factor that multiplied the instability in the Middle East through attacks on water resources and conduits. Hence security conceptualization at large had to be re-interpreted and be analyzed within the limits of emerging security transformation.

\section{The Water Related Incidents in Iraq, Syria and Turkey between 2000 - 2019}

Water has become an apparatus of strategic superiority other than vital substance of life for survival. For this reason, water basin and resources or selected as targets to force the other side to abide by imposed demands or rules, obtain advantage during the negotiations, or absolute physical objectives to have the opponents derived of vital needs. Hence water has prominence for the security of human, social groups, non-state actors, society at all, and state as well. In this context, water resources and conduits - dams, canals, irrigation systems, and resources themselves, have become the targets of varying networks within the frame of terror acts or under the preferred tactics of parties in the civil wars. For this reason, there is a common concern for these three states and sub-state actors that water need to be water and its security must be sustainable. Mainly the outcomes of de-securitized water resources are multiplier or igniter of the other security concerns, say food, health, drought.

\section{Conflicts and Water Security in Iraq}

Iraq had faced the intervention of the USA and its allies in 2003. Wide spread of violence, in the forms of varying sorts of conflicts, affected the overall security of Iraq and daily lives of fragmented Iraqi society based on ethnicity, sectarianism, radicalism, or ideology. The conflicts turned out to have a course of threatening the security of environment and human. In this sense water resources and irrigation appeared as the popular targets either to punish the society of perceived 'enemies', endangering living conditions of innocent civilians and faith of the overall public. Incapable of the security forces could not protect the water irrigation against terror acts ruining the overall water networks. Water had become the main effort of the Iraqi state and invading foreign forces. 


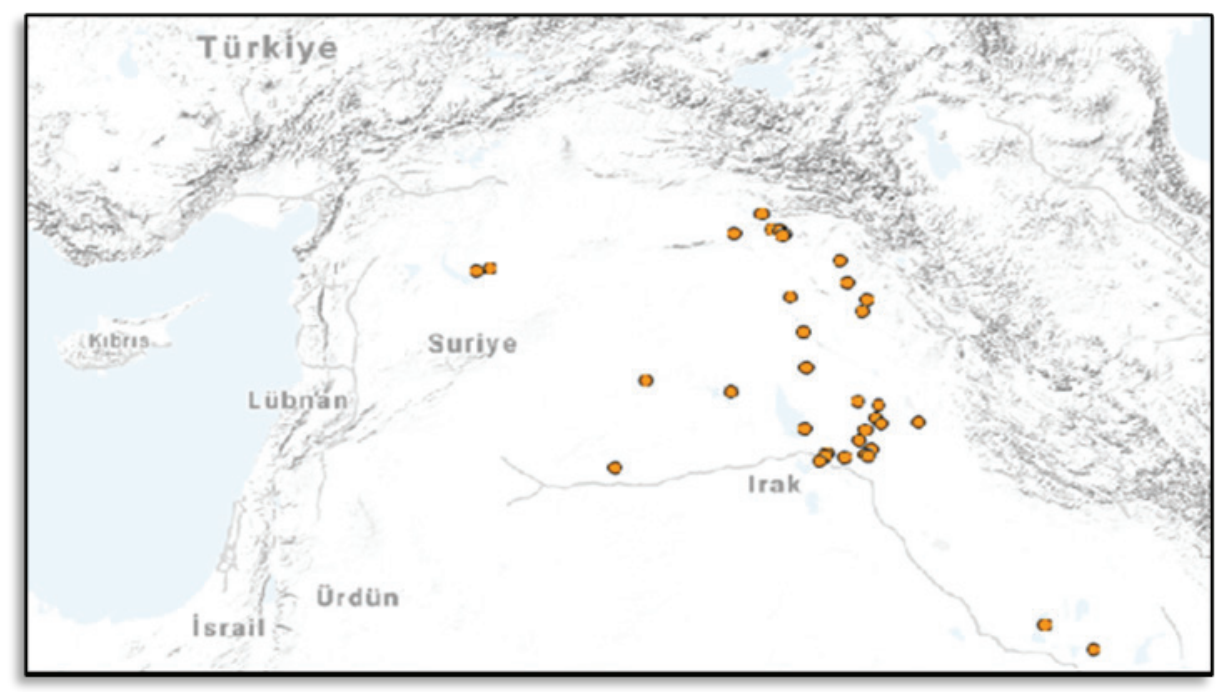

Figure 3. Water Related Events in Iraq between 2000-2018

Source: (Pacific Institute, 2021).

Figure-3 indicates the geographic distribution of attacks and relevant events in Iraq. The context and features the events will clarify the characteristics of the water-related security. In this sense, Table-1 covers the identified events and water conflicts in Iraq onward 2003. Events related to water conflicts in the table are important to determine the purpose or subject of conflicts. In this respect, the table makes it easy to review the distribution of conflicts over the years and to perform comparative analysis.

Table 1

Events and Conflicts On Water In Iraq ${ }^{1}$

\begin{tabular}{|l|l|l|c|}
\hline Year & Title & Event & Source \\
\hline 2003 & $\begin{array}{l}\text { Water systems dam- } \\
\text { aged }\end{array}$ & $\begin{array}{l}\text { Water systems were damaged during the US war } \\
\text { in Iraq. Water systems and dams have been the } \\
\text { military targets of the US forces with missile at- } \\
\text { tacks in order to provide regional control. }\end{array}$ & (Keele, 2003) \\
\hline 2003 & Iraq pipeline targeted & $\begin{array}{l}\text { Armed groups bombed a main water pipeline in } \\
\text { Baghdad. }\end{array}$ & $\begin{array}{c}\text { (Tierney \& Worth, } \\
\text { 2003) }\end{array}$ \\
\hline 2003 & $\begin{array}{l}\text { Water treatment plant } \\
\text { damaged }\end{array}$ & $\begin{array}{l}\text { Abu Nawas station, which supplies water to Sadr } \\
\text { city in Baghdad, has been damaged by regional } \\
\text { conflicts. }\end{array}$ & $\begin{array}{c}\text { (International Com- } \\
\text { mittee of the Red } \\
\text { Cross (ICRC), 2009) }\end{array}$ \\
\hline 2003 & $\begin{array}{l}\text { Bomb Attack on the } \\
\text { water source }\end{array}$ & $\begin{array}{l}\text { Water systems became unusable with the explo- } \\
\text { sion of a bomb placed on the water main line. } \\
\text { With the disruption of the pipelines, a flood oc- } \\
\text { curred in Baghdad. }\end{array}$ & $\begin{array}{l}\text { (RAND Database of } \\
\text { Worldwide Terrisom } \\
\text { Incidents (RDWTI), } \\
\text { 2019) }\end{array}$ \\
\hline
\end{tabular}

1 Table-1 The events are derived and analysed by the authors from the Pacific Institute, World Water and other open sources, covering the years 2003 and 2019. 
Table 1

Events and Conflicts On Water In Iraq

\begin{tabular}{|c|c|c|c|}
\hline Year & Title & Event & Source \\
\hline 2005 & $\begin{array}{l}\text { Water pipeline } \\
\text { targeted }\end{array}$ & $\begin{array}{l}\text { Thousands of people were unable to access water } \\
\text { and were affected in the attack on Iraq's water } \\
\text { pipeline in Baghdad. }\end{array}$ & $\begin{array}{l}\text { RAND Database of } \\
\text { Worldwide Terrorism } \\
\text { Incidents 2018; New } \\
\text { Humanitarian, The } \\
2005\end{array}$ \\
\hline 2005 & $\begin{array}{l}\text { Three Iraqis people } \\
\text { carrying water were } \\
\text { targeted. }\end{array}$ & $\begin{array}{l}\text { Three Iraqis were targeted by a group. Three Iraqis } \\
\text { were carrying water to a military base near the } \\
\text { Iraqi city of Taji. }\end{array}$ & $\begin{array}{l}\text { (RAND Database of } \\
\text { Worldwide Terrisom } \\
\text { Incidents (RDWTI), } \\
\text { 2019) }\end{array}$ \\
\hline 2005 & $\begin{array}{l}\text { Mortar Attack on the } \\
\text { water plant }\end{array}$ & $\begin{array}{l}\text { As a result of the mortar attack, the flow of water } \\
\text { to a water plant in Baghdad, Iraq, was interrupted. }\end{array}$ & $\begin{array}{l}\text { (The Global Terror- } \\
\text { ism Database (GTD), } \\
\text { 2019) }\end{array}$ \\
\hline 2005 & $\begin{array}{l}\text { Civilians working } \\
\text { in the water project } \\
\text { were targeted. }\end{array}$ & $\begin{array}{l}\text { Civilians working on a water project in Al-Faris in } \\
\text { Iraq have been targeted. } 40 \text { people were affected } \\
\text { by the attack. Among them, } 18 \text { people died. }\end{array}$ & $\begin{array}{l}\text { (The Global Ter- } \\
\text { rorism Database } \\
(\mathrm{GTD}), 2019) \text { ID. } \\
200507260001\end{array}$ \\
\hline 2006 & $\begin{array}{l}\text { Water Project Tar- } \\
\text { geted in Baqubah }\end{array}$ & $\begin{array}{l}\text { Hussein Ali Atiyah, who worked on the Baqubah } \\
\text { water project and was the project manager, was } \\
\text { killed by gunmen. }\end{array}$ & $\begin{array}{l}\text { (RAND Database of } \\
\text { Worldwide Terrisom } \\
\text { Incidents (RDWTI), } \\
\text { 2019) }\end{array}$ \\
\hline 2006 & $\begin{array}{l}\text { Drinking water of } \\
\text { Ayn al-Asad military } \\
\text { base targeted }\end{array}$ & $\begin{array}{l}\text { The drinking water of the U.S.-owned Ayn al- } \\
\text { Assad base was targeted. Pipes belonging to the } \\
\text { Water Treatment Plant were damaged. }\end{array}$ & $\begin{array}{l}\text { (The Global Ter- } \\
\text { rorism Database } \\
\text { (GTD), 2019) ID. } \\
200604100025\end{array}$ \\
\hline 2007 & Water station targeted & $\begin{array}{l}\text { The water station, located in the Al-Khalis District } \\
\text { of Diyala Governorate in Iraq, was targeted. At } \\
\text { least } 33 \text { people were killed in the attack, local } \\
\text { sources statements. }\end{array}$ & $\begin{array}{l}\text { (RAND Database of } \\
\text { Worldwide Terrisom } \\
\text { Incidents (RDWTI), } \\
\text { 2019) }\end{array}$ \\
\hline 2007 & Tigris river polluted & $\begin{array}{l}\text { After the conflict in Iraq's Baiji region, oil con- } \\
\text { taminated Tigris water resources. }\end{array}$ & $\begin{array}{l}\text { (RAND Database of } \\
\text { Worldwide Terrisom } \\
\text { Incidents (RDWTI), } \\
\text { 2019) }\end{array}$ \\
\hline 2008 & $\begin{array}{l}\text { Water pipeline } \\
\text { targeted by armed } \\
\text { groups }\end{array}$ & $\begin{array}{l}\text { Armed groups targeted Iraq's water pipeline in } \\
\text { Baghdad. After the attacks, drinking water could } \\
\text { not be delivered to Baghdad's Adhamiyah, Rusafa } \\
\text { and Karrada districts. }\end{array}$ & $\begin{array}{l}\text { (The Global Ter- } \\
\text { rorism Database } \\
\text { (GTD), 2019) ID. } \\
200810300021\end{array}$ \\
\hline 2014 & $\begin{array}{l}\text { Dam Targeted by } \\
\text { DAESH Armed } \\
\text { Groups }\end{array}$ & $\begin{array}{l}\text { DAESH militants have seized the Fallujah Dam in } \\
\text { Iraq. The waterways were confiscated. }\end{array}$ & (Coles, 2014) \\
\hline 2014 & $\begin{array}{l}\text { Dam was Targeted by } \\
\text { DAESH in Musul }\end{array}$ & $\begin{array}{l}\text { Mosul dam in Iraq was captured by DAESH } \\
\text { groups in August } 2014 .\end{array}$ & (Schwartzstein, 2014) \\
\hline 2014 & $\begin{array}{l}\text { Fallujah dam used as } \\
\text { a weapon by DAESH }\end{array}$ & $\begin{array}{l}\text { The Fallujah Dam was closed by DAESH and the } \\
\text { area was flooded. Thus, agricultural areas were tar- } \\
\text { geted, and the people of the region were forced to } \\
\text { migrate. As a result, more than } 10,000 \text { homes and } \\
200 \text { square kilometers of farmland were flooded in } \\
\text { the city of Abu Ghraib. }\end{array}$ & $\begin{array}{c}\text { (UN Security Council, } \\
\text { 2017) }\end{array}$ \\
\hline 2014 & $\begin{array}{l}\text { Access to water } \\
\text { denied }\end{array}$ & $\begin{array}{l}\text { DAESH targeted the water supply of the Christian } \\
\text { town of Qaraqosh. } \\
\text { As a result, } 50,000 \text { people living in the town had } \\
\text { to migrate from the region. }\end{array}$ & $\begin{array}{c}\text { (UN Security Council, } \\
\text { 2017) }\end{array}$ \\
\hline
\end{tabular}


Table 1

Events and Conflicts On Water In Iraq ${ }^{1}$

\begin{tabular}{|c|c|c|c|}
\hline Year & Title & Event & Source \\
\hline 2015 & $\begin{array}{l}\text { Ramadi Dam was } \\
\text { closed }\end{array}$ & $\begin{array}{l}\text { DAESH groups in Iraq have blocked the water } \\
\text { flow of the Ramadi dam in an attempt to gain } \\
\text { geographical superiority. The dam's water was } \\
\text { diverted in different directions. }\end{array}$ & $\begin{array}{l}\text { Alkhshali and Smith- } \\
\text { Spark 2015; Coles } \\
2015\end{array}$ \\
\hline 2015 & $\begin{array}{l}\text { Water flow is blocked } \\
\text { by DAESH }\end{array}$ & $\begin{array}{l}\text { The water resources and systems in the regions } \\
\text { where Shiite communities live (Babylon, Karbala, } \\
\text { Najaf and Kadisiy) were targeted. }\end{array}$ & $\begin{array}{c}\text { (UN Security Council, } \\
\text { 2017) }\end{array}$ \\
\hline 2016 & $\begin{array}{l}\text { Water pipeline tar- } \\
\text { geted by DAESH }\end{array}$ & $\begin{array}{l}\text { DAESH targeted water pumping stations to cut } \\
\text { waterways. As a result, thousands of people were } \\
\text { left without water in Mosul. }\end{array}$ & $\begin{array}{l}\text { (Tawfeeq \& Ab- } \\
\text { delaziz, 2016) }\end{array}$ \\
\hline 2017 & $\begin{array}{l}\text { DAESH diverts a } \\
\text { river and cuts the } \\
\text { water }\end{array}$ & $\begin{array}{l}\text { DAESH groups control a river passing through } \\
\text { Abu Karmah, Mukdadiyah, Diyala area, closing } \\
\text { the water flow to the villages. }\end{array}$ & $\begin{array}{l}\text { (The Armed Con- } \\
\text { flict Location \& } \\
\text { Event Data Project } \\
\text { (ACLED), 2019) }\end{array}$ \\
\hline 2018 & $\begin{array}{l}\text { Drinking Water } \\
\text { Targeted }\end{array}$ & $\begin{array}{l}\text { Tens of thousands of people have been sickened } \\
\text { by contaminated drinking water in Basra, Iraq, due } \\
\text { to clashes and the targeting of water supplies. }\end{array}$ & $\begin{array}{c}\text { Trew 2018; } \\
\text { Al Jazeera 2018b; } \\
\text { Amnesty International } \\
\text { 2018a }\end{array}$ \\
\hline
\end{tabular}

The table points that the militias committed 23 attacks to water resources directly targeting them and with no concern on the outcomes of these attacks. When we examine the data in the tables, we see that the basic motivation was to remind the weakness of the security forces by emphasizing their capacity of having the public be deprived of basic needs as far as they are not satisfied with what they aim. In other words, the attacks were designed to tell their strength in the eyes of the public, degrading the security forces. It was apparent in 2005, 2006, 2007, 2014, 2015 events, as mentioned in Table 1. An example of this situation is the targeting of the town of Karakosh, where Christians live, and the forcing of 50,000 people to emigrate from the region. The attacks targeted the assigned personnel and dedicated properties which are enrolled or owned by the Iraqi state. The militias did not hesitate to ruin the water infrastructure that provide service to the competing social entity with a motivation of punishing the sectarian identity of them. It became a revenge methodology surpassing the basic humanitarian rights and needs by preventing access to clean water. In this context, 20 attacks between 2003 and 2018 affected water resources and irrigation systems of which 18 of them were directly targeting the water system while two of them were directed to the employed individuals who ran the irrigation. Consequently, the countries like Iraq, which do have multi-ethnicity and sectarian division in the society may have vulnerability in terms of water security.

\section{Conflicts and Water Security in Syria}

Environmental degradation and water shortage were common during the Syrian conflict after 2011. Water resources were direct targets to be captured as a leverage to bargaining with the state actors and force civilians to leave the habitat where they were living. In this sense, water irrigation and purification plants appeared to be essential targets to be destroyed either by terror networks or Assad Regime. Hence, water was the main tool to force the other public evacuated designated regions leading to the demographic change in Syria. 


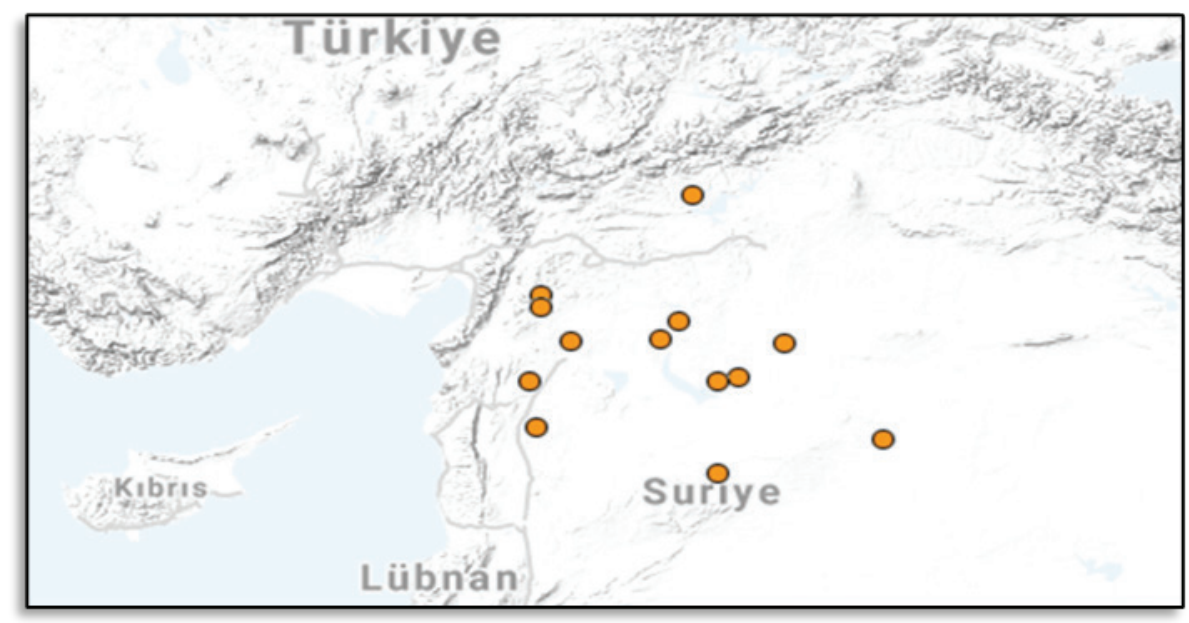

Figure 4. Water Affiliated Events in Syria between 2000-2019

Source: (Pacific Institute, 2021).

Figure-4 indicates the conflicts or affiliated events in Syria onward 2000. The attacks were instigated by both the Regime, representing the state authority, and terror cells like DAESH and Democratic Union Party (PYD). The basic instinct is to establish control over the water and force 'competing' societies either to obey the imposed regulations or evacuate the region by means of sabotages. Table- 2 covers the events, affiliated with the water resources and conduits, in Syria between 2000 and 2019. In order to make a comparative comparison between the water conflicts in Syria and Iraq and Turkey, emphasis has been given to the conflicts that coincide with the same periods. As can be seen from the table, there have been some attacks in Syria caused not only by non-state actors, but also by coalition forces. These attacks also directly or indirectly affected Water Resources.

Table 2

Events and Conflicts on Water In Syria ${ }^{2}$

\begin{tabular}{|l|l|l|c|}
\hline Year & Title & Event & Source \\
\hline 2012 & $\begin{array}{l}\text { Syrian Civil War battle dam- } \\
\text { ages Aleppo pipeline }\end{array}$ & $\begin{array}{l}\text { Water systems have been targeted and } \\
\text { damaged in Aleppo during the conflicts. } \\
\text { As a result, drinking water could not be } \\
\text { supplied to the city. }\end{array}$ & $\begin{array}{c}\text { (BBC News, } \\
\text { 2012) }\end{array}$ \\
\hline 2012 & $\begin{array}{l}\text { Dam is captured by Armed } \\
\text { Groups }\end{array}$ & $\begin{array}{l}\text { Some of the armed groups who were clash- } \\
\text { ing with the Bashar al-Assad government } \\
\text { targeted the Tishrin hydroelectric barage in } \\
\text { order to control the strategic locations of } \\
\text { the region. }\end{array}$ & (Mroue, 2012) \\
\hline 2014 & $\begin{array}{l}\text { "Free Syrian Army cuts off } \\
\text { water supply to Wadi Barada" }\end{array}$ & $\begin{array}{l}\text { The Free Syrian Army has taken control of } \\
\text { the Ain El-Fijah water supply. }\end{array}$ & (Reznicck, 2016) \\
\hline
\end{tabular}

2 Table-2. The points and events were analyzed and interpreted through data collected through World Water and other media sources. The Syrian events listed in the chronology were created by the authors taking into account the period between 2000-2019. 


\begin{tabular}{|c|c|c|c|}
\hline 2015 & $\begin{array}{l}\text { Terror attack on waterline in } \\
\text { Aleppo }\end{array}$ & $\begin{array}{l}\text { Al-Nusra group militants targeted the main } \\
\text { pipeline carrying water from the Euphrates } \\
\text { River to the city of Aleppo. }\end{array}$ & (Reznicck, 2016) \\
\hline 2015 & $\begin{array}{l}\text { Russia military targeted } \\
\text { the water treatment plant in } \\
\text { Aleppo. }\end{array}$ & $\begin{array}{l}\text { Russia's military forces targeted the El- } \\
\text { Khafsa water treatment plant in the city of } \\
\text { Aleppo, mistaking it as an oil production } \\
\text { facility. According to UNICEF, this attack } \\
\text { caused serious damage to the environment } \\
\text { and about } 3.5 \text { million people were affected } \\
\text { by water shortages. }\end{array}$ & (Miles, 2015) \\
\hline 2016 & $\begin{array}{l}\text { The water supply to Damascus } \\
\text { was cut off }\end{array}$ & $\begin{array}{l}\text { Armed groups cut off the water supply in } \\
\text { Ain al-Fijah. As a result, water production } \\
\text { in the capital Damascus has decreased by } \\
90 \% \text {. }\end{array}$ & (Reznicck, 2016) \\
\hline 2016 & $\begin{array}{l}\text { Tishreen Dam was targeted by } \\
\text { DAESH }\end{array}$ & $\begin{array}{l}\text { "DAESH attacked the Tishrin Dam on the } \\
\text { Euphrates River in Syria." }\end{array}$ & $\begin{array}{l}\text { (The Wilson } \\
\text { Center, 2019) }\end{array}$ \\
\hline 2017 & The capital is often dehydrated & $\begin{array}{l}\text { Wadi Barada and Ain El Fija water re- } \\
\text { sources targeted }\end{array}$ & (Hubbard, 2017) \\
\hline 2017 & $\begin{array}{l}\text { "US Coalition destroys main } \\
\text { pipeline to Raqqa" }\end{array}$ & $\begin{array}{l}\text { The U.S.-led coalition against DAESH has } \\
\text { targeted the main pipeline that supplies } \\
\text { water to Raqqa. }\end{array}$ & (Omara, 2017) \\
\hline 2017 & $\begin{array}{l}\text { Syrian forces took back water } \\
\text { resources and systems after } \\
\text { conflicts with DAESH }\end{array}$ & $\begin{array}{l}\text { Syrian government forces have recaptured } \\
\text { water treatment and pumping facilities for } \\
\text { the city of Al Khafsa from DAESH con- } \\
\text { trol, restoring water supplies to the region. }\end{array}$ & $\begin{array}{l}\text { (TRT World, } \\
\text { 2017) }\end{array}$ \\
\hline 2019 & $\begin{array}{l}\text { Water station targeted in north- } \\
\text { west Syria }\end{array}$ & $\begin{array}{l}\text { "At least } 29 \text { water stations serving approxi- } \\
\text { mately } 610,000 \text { people were destroyed due } \\
\text { to terrorist attacks and violent conflict in } \\
\text { northwest Syria." }\end{array}$ & $\begin{array}{l}\text { (US Agency for } \\
\text { International } \\
\text { Development, } \\
\text { 2019) }\end{array}$ \\
\hline
\end{tabular}

The Syrian case clearly indicates that combatants directly targets the water resources and irrigation for strategic superiority upon the opposing party. The expectation was to have the 'adversary' move towards a desired direction and purify a portion of land from the other ethnicity or sect, as was witnessed especially in Iraq even though it was harsher and perceived adversaries were civilians. In Iraq, DAESH forced 50.000 residents of the Christian town of Karakosh in 2014, and in 2015 while committing attacks to Babylon, Karbala, Najaf and Kadisiy where Shiite communities are living. Like Iraq, water reservoirs and resources were selected as high value targets to be destroyed. In this context, 10 of the 11 attacks targeted directly to control the water resources. Munbic city, as an example, was both targeted by DAESH and PYD to control the water dam and irrigation system. The water system, then, were strategic for the mentioned actors to achieve political objectives of either terror cells or Assad Regime.

\section{Terrorist Attacks and Water Security in Turkey}

When compared to Iraq and Syria, Turkey is richer in terms of water resources and built irrigation systems. The clean and drinkable water of the eastern Anatolia is the essential reserve for Turkey for irrigation and, in the meantime, energy production that makes the water resources and reservoir vulnerable to the terror acts of Kurdistan Workers' Party (PKK) and affiliated networks. PKK's main organization is located in Syria and Iraq with 
a consequence of having terror acts in Turkey concentrated in the vicinity of the border with these states. One characteristic of the attacks to water resources and the irrigation system is that they target the Turkish state's capabilities and credibility rather than individuals or local society. The attack to Silvan Dam of Diyarbakır is a significant case for this argument (The Jordan Times, 2015). Even though climate change is a concern for Turkish authorities for the amount and quality of water, terror acts are the essential threat to challenge the actual potential of water reservoirs. Figure-5 indicates the locations of the witnessed terror acts.

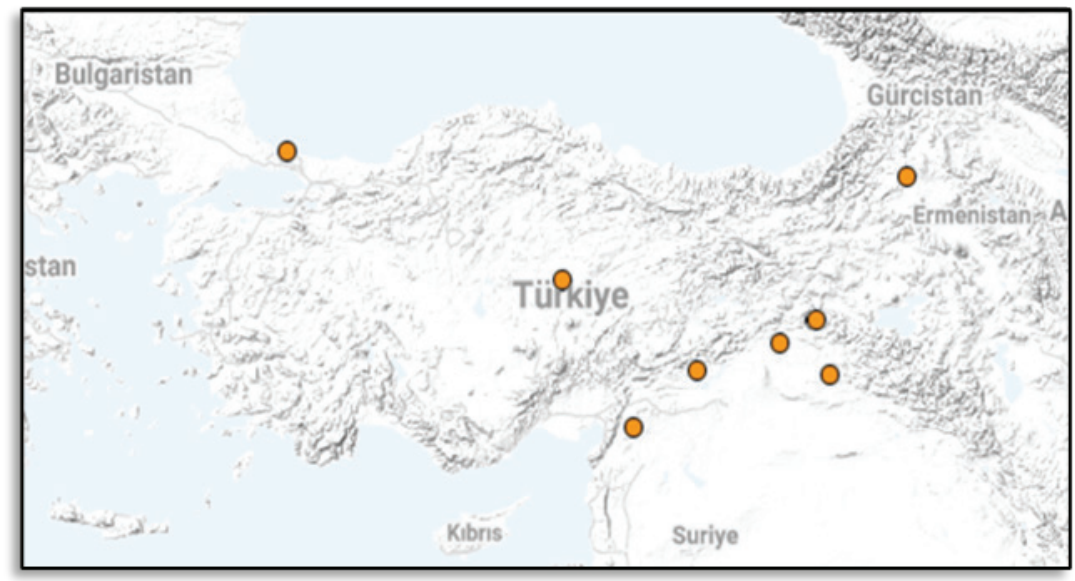

Figure 5. The Events Threatening the Water Security in Turkey between 2000 and 2019 Source: (Pacific Institute, 2021).

Table-3 points that the attacks occurred mainly close to the borders of Turkey, but they were away from the levels of attacks numbers in Iraq and Syria. Table-3 indicates that these attacks are heavily affiliated with terrorist agenda of the mentioned organization. Hence Turkey's threat perception is based on terrorism rather than ethnic or sectarian grievances in the society.

Table 3

Events and Conflicts on Water in in Turkey

\begin{tabular}{|l|l|l|c|}
\hline Year & Title & Event & Source \\
\hline 2012 & Attack on The Dam & $\begin{array}{l}\text { The PKK terror group attacked water dam sites } \\
\text { and construction's in Turkey, burning containers } \\
\text { where workers were staying. }\end{array}$ & (CNN Türk, 2012) \\
\hline 2014 & $\begin{array}{l}\text { Hydroelectric Power } \\
\text { Plant Targeted }\end{array}$ & $\begin{array}{l}\text { A hydroelectric power plant in Kars province } \\
\text { has been targeted by the PKK terrorist organiza- } \\
\text { tion. Three terrorists were killed in the clash. }\end{array}$ & $\begin{array}{c}\text { (Hurriyet Daily News, } \\
\text { 2014) }\end{array}$ \\
\hline 2015 & $\begin{array}{l}\text { Sabotage to the Dam } \\
\text { Construction }\end{array}$ & $\begin{array}{l}\text { An attack was organized in order to sabotage } \\
\text { and delay the work of the Silvan barrage in } \\
\text { Diyarbakir. }\end{array}$ & (CNN Türk, 2012) \\
\hline
\end{tabular}

3 Table-3. The points and events were analyzed and interpreted through data collected through World Water and other sources. The events of Turkey listed in the chronology were created by the authors taking into account the period between 2000-2019. 


\begin{tabular}{|l|l|l|c|}
\hline 2015 & $\begin{array}{l}\text { Soldiers Guarding } \\
\text { the Dam Targeted }\end{array}$ & $\begin{array}{l}\text { PKK militants attacked Turkish soldiers guard- } \\
\text { ing a hydroelectric dam in the Kulp district } \\
\text { of Diyarbakir with rockets and long-range } \\
\text { weapons. }\end{array}$ & $\begin{array}{c}\text { (The Jordan Times, } \\
\text { 2015) }\end{array}$ \\
\hline 2016 & $\begin{array}{l}\text { Water sources } \\
\text { targeted }\end{array}$ & $\begin{array}{l}\text { A bomb attack was carried out by the PKK } \\
\text { terrorist organization on a waterline connected } \\
\text { to Mardin. }\end{array}$ & $\begin{array}{l}\text { (The Global Ter- } \\
\text { rorism Database } \\
\text { (GTD), 2019) ID. } \\
\text { 201604170038 }\end{array}$ \\
\hline
\end{tabular}

The attacks point out the undertakings that aim to breach the state authority through water resources and infrastructure. For example, in 2012, the PKK terrorist organization burned containers for accommodation around the water dams and construction sites where construction workers were staying. Besides, the terror network attacked the Silvan dam and sabotaged the construction around it in 2015. The dams and relevant constructions efforts threatens the already bases and transport routes of PKK at the bottoms of the river valleys that pose a survivability risk for the network. Hence the targets aim at denying or delaying the constructions of water infrastructure. Meanwhile the attack in Mardin City appears to be a revenge-oriented activity due to the removal of the city mayor, who had been identified assisting PKK and be replaced by the Governor to the Mayor's Office. Eventually it has been observed in Turkey, similar to Iraq and Syria, that water, resources and infrastructure were direct targets of the terror attacks with a conscious target selection. The objective of such attacks is to downgrade the water security and deliver the message to the public that PKK is capable and deny the activities of the state authorities by strategically planned plots.

\section{Findings}

There is a proportional increase in the number of attacks and relevant conflicts in Iraq, Syria and Turkey between 2000 and 2019 in terms of the attacks to water resources and infrastructure. If the twenty-year-term, 1980 - 2020, is compared to the 2000-2019 term, the preceding era witness 8 conflicts while the latter has 39 that were not among the states but non-states ones. Figure- 6 illustrates the percentage of these conflicts, which were totally sabotages or attacks by the terror networks. In this sense $83 \%$ of the conflicts occurred in the latest 20 years. Hence terrorism has become a factor that threatens water conduits, infrastructure and resources with a sharp increase pending to internal threat types. 
The Proportional Comparison of Water Related Conflicts in Iraq, Syria and Turkey

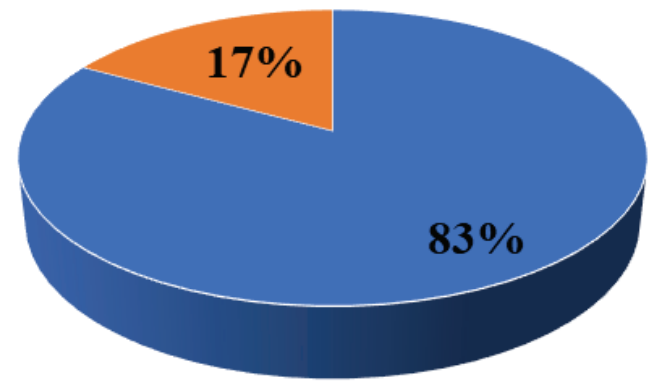

$\square$ 2000-2019

- 1980-2000

Figure 6. The Proportional Comparison of Water Related Conflicts in Iraq, Syria and Turkey. ${ }^{4}$

If the trend of afore mentioned conflicts is scrutinized pending to individual countries, there appears a difference among the countries, most probably because the micro, mezzo and macro level established authorities.

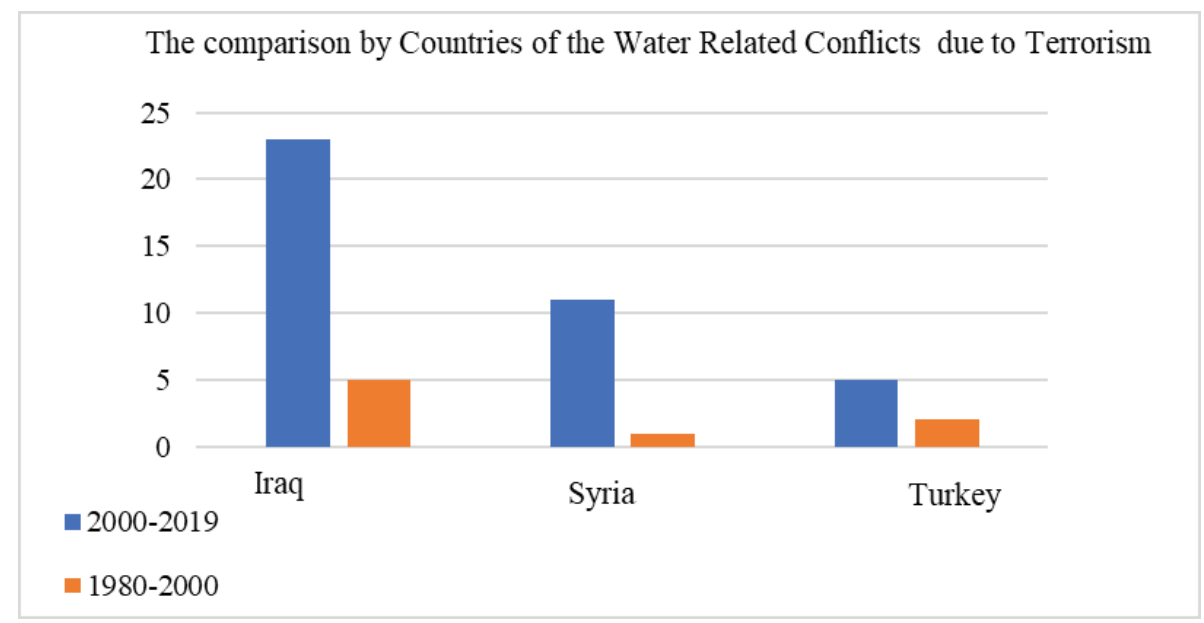

Figure 7. The comparison by Countries of the Water Related Conflicts due to Terrorism ${ }^{5}$

Figure-7 indicates that there is an increase in the mentioned three countries during the demarcated eras. But Iraq has become the one that most attacks were observed in comparison to Syria and Turkey. Fragmentation of society and the inability of the state

4 Figure-6 has been presented by the data derived from the Pacific Institute.

5 The Figure-7 has been illusrtated by the data derived from the www.worldwater.org/conflict/map/. 
mechanism at micro and mezzo levels could be the reasoning for this trend. In addition, it is seen that the motivation of attacks differs in relevance with the examined countries. Terrorist attacks in Turkey have directly targeted dams and water resources in order to preserve the habitat of the terror cells in rural. It differs in Iraq and Syria because DAESH aimed at punishing the ethnic groups with differing descents like the Christian town of Karakosh in 2014 and in 2015, and Babel, Karbala, Najaf, Kadiya, where the Shiite population densely lived as delineated in Figure-7. On the other hand, the trend in Turkey differs if the terms 2000-2019 and 1980-2000 are compared. The second half of 20002019 era coincides with the Syrian crises while the era between 1980 and 2000 was more oriented to directly challenge the Turkish security forces and obtain popular support by the strategy of coercive persuasion.

The dispersion of attacks pending to mentioned states are also important. As can be seen in Figure-8, the percentage of the attacks is the highest in Iraq by $59 \%$ between $2000-2019$. Syria follows by $28 \%$ and Turkey by $13 \%$. The data indicates that the threat to the security of water is due to terror attacks, mainly in Iraq.

\section{The Distribution of Water-relevant Conflicts in Iraq, Syria and Turkey between 2000-2019}

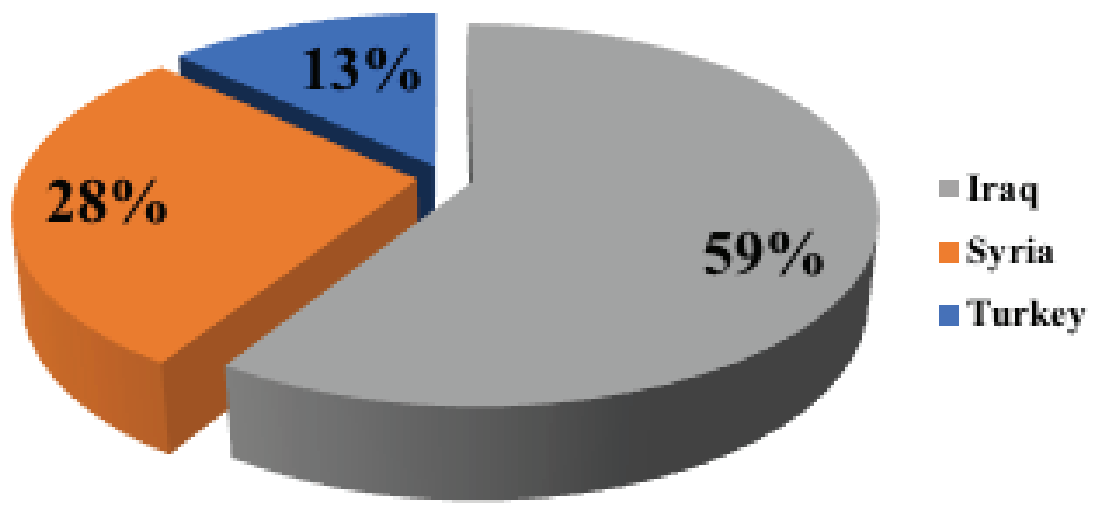

Figure 8. The Distribution of Water-relevant Conflicts in Iraq, Syria and Turkey between 2000-20196

If the types and targets of the attacks are analyzed, 34 of the overall attacks in three of the mentioned countries directly targeted water resources and infrastructure. Three of the attacks were against the individuals who worked for running water networks on behalf of the authorities. These attacks aim at either denying the water infrastructure's construction or asymmetric one due to revenge purposes. But the majority, as can be seen from the numbers, directly targets the water resources and service.

In addition to the above data, it is important to review all terrorist attacks in recent years and to review how many of them are intended for natural resources. Data from the Terrorism

6 Figure- 8 has been presented by the data derived from the Pacific Institute. 
Analysis Platform (TAP) of SETA Foundation and STM, which has been regularly updated, covers 30 years of terrorist attacks in the wider globe with a categorization and filtering architecture. Data covering 2000-2019 were analyzed and examined, the total terrorist attacks in Syria, Iraq and Turkey were recorded as 1,160. When we exterminate all attacks; 710 of these attacks were organized by the PKK, 414 by DAESH, 15 by Fethullah Terrorist Organization, 9 by Al-Qaida in Iraq, 3 by YPG, 3 by the Marxist-Leninist Communist Party, 5 by the Revolutionary People's Liberation Party/Front DHKP/C and 1 by the Maoist Communist Party of Turkey. Among all these attacks, a total of 56 attacks targeted natural resources in Iraq, Syria and Turkey between 2015 and 2019. Hence the trend of targeting natural resources has been an emerging tactic after 2015, mainly by PKK and DAESH. On the other hand, TAP does not clarify how many of these attacks includes the attacks towards water resources, but generally covers mining fields, energy plants or water resources as well. Interestingly 44 of the 56 terrorist attacks took place against Turkey, and 49 of them were carried out by the PKK. The rest seven attacks were carried out by DAESH. Eventually, natural resources have increasingly become a cost-effective and influential method of targeting the state actors while displaying show of force in the eyes of the public (Terrorism Analysis Platform (TAP), 2021)

\section{Conclusion}

Water security has a long historical discourse. The conflicts upon water were to control the usage of it by the state actors though; the emerging conflicts on water are at the micro and mezzo level after the years 2000s. Hence, the security of water needs to be re-interpreted due to witnessed transformation of challenging state actor, competing with the adverse ethnic or sectarian entity or targeted state capabilities by the terror networks. Whatever agenda the revisionist networks pursues, the attacks affect, and to some extend target, individuals first, societies and state afterwards.

As can be concluded from the Figures 2, 3 and 4, the attacks to water resources and infrastructure in Iraq, Syria and Turkey are due to terror acts after 2000. The common characteristic of the mentioned attacks are that water has become a asymmetric weapon against the state authority and rival social groups by $59 \%$ in Iraq, $28 \%$ in Syria and 13\% in Turkey. Hence Iraq has the greatest number of attacks to water related infrastructure in comparison to the other states probably because of the social division of the country. The comparison of two twenty-years-term indicates that the trend of committing attacks to water infrastructure is in an increase which makes it a frequented method of challenging stability. Such a tendency indicates the security of the water as a common threat perception of not only the states but also individuals and societies.

The comparison of the twenty-years-terms (1980-2000 vs. 2000-2019) points to the precedent era that has $17 \%$ of the overall number of water-related attacks while $83 \%$ during the latter in the three countries. It shows that water has become an important of the frequented objective types for the terror networks and insurgency for the latest two decades. On the other hand, the same era brought new conceptualizations like proxy and hybrid warfare in mainly Iraq and Syria. As the weight of such new conflicts boldens the conflictual environment, water has become the basis of struggle between the nonstate actors (DAESH, PKK etc.), including sub terror networks (Al-Nusra groups etc.), 
that also conflicts have linkage to external state actors (The U.S.-led coalition, Russia's military forces etc.). The water in the conflict-laden states and regions has become a methodology for demographic change other than revenge or proving strength. At the mean time water appears as blackmailing goods to urge the public and adversaries to comply with the demands.

Peer-review: Externally peer-reviewed.

Conflict of Interest: The authors have no conflict of interest to declare.

Grant Support: The authors declared that this study has received no financial support.

\section{References}

Altunbaş, İ. (2013). Ortadoğu'da Yeni Bir Senaryo: Su Savaşları. Minerva Dergisi, vol.? (12), 1-7. https://www. academia.edu/4779386/Ortado\%C4\%9Fuda_Yeni_Bir_Senaryo_Su_Sava\%C5\%9Flar\%C4\%B1, Accesed date:: 04.04.2019

Aydın, M. (2004, Eylül). Uluslararası İlișkilerin “Gerçekçi” Teorisi: Kökeni, Kapsamı, Kritiği. Uluslararası Illişkiler Dergisi, 1(1), s. 33-60. https:/www.uidergisi.com.tr/wp-content/uploads/2010/09/UluslararasiIliskilerin-Gercekci-Teorisi.pdf, Accesed date:: 15.10.2019

Aytaç, G. B. (2018, Haziran). Feminist Yaklaşım Çerçevesinde İnsan Güvenliği: Sivil Toplum Gözüyle Irak Örneği. Marmara Üniversitesi Kadın ve Toplumsal Cinsiyet Araştırmaları Dergisi, 1(2), s. 9-23. doi:DOI: 10.26695/mukatcad.2018.12

Baran, T., \& Macar, E. (2017). Değişen Güvenlik Yaklaşımları Örneğinde Kopenhag Okulu'nun Toplumsal Güvenlik Yaklaşımı. Uluslararası Sosyal Araştırmalar Dergisi, 10(54), 252-259.

BBC News. (2012, September 08). Aleppo water supply cut as Syria fighting rages. British Broadcasting Corporation (BBC): https://www.bbc.com/news/world-middle-east-19533112, Erişim tarihi:18.12.2019

Buzan, B. (1983). People, States, and Fear: National Security Problem in International Relations (Cilt 8). Brighton: Harvester Wheatsheaf.

CNN Türk. (2012, October 01). PKK baraj inşaatını bastı. cnnturk.com: https://www.cnnturk.com/2012/ turkiye/10/01/pkk.baraj.insaatini.basti/678742.0/index.html; Accesed date: 02.02.2020

Coles, I. (2014, April 11). Iraq insurgents use water as weapon after seizing dam. Reuters: http://reut.rs/ TnvUH6, Accesed date: 22.12.2019

Dikmen, Ç. (2004). Enerji ve Çevre Ekseninde Ulusal Güvenlik. Görüş, 31-32. http://www.maden.org.tr/ resimler/ekler/43de7cf7ba769c7 ek.pdf Accesed date: 22.11 .2019

Gleick , P., \& Heberger, M. (2013). Water and Conflict: Events, Trends, and Analysis (2011-2012). The World's Water, 8, 159-171. http://worldwater.org/wp-content/uploads/2013/07/www8-water-conflict-events-trendsanalysis.pdf

Hammer, J. (2013, June). Is a Lack of Water to Blame for the Conflict in Syria? Smithsonian.com: https://www. smithsonianmag.com/innovation/is-a-lack-of-water-to-blame-for-the-conflict-in-syria-72513729/

Hubbard, B. (2017, January 05). A New Casualty of Syria's War: Drinking Water in Damascus. The New York Times: https://www.nytimes.com/2017/01/04/world/middleeast/a-new-casualty-of-syrias-war-drinkingwater-in-damascus.html

Hurriyet Daily News. (2014, October 27). Turkish gov’t toughens Kurdish bid stance after attack. www. hurriyetdailynews.com: https://www.hurriyetdailynews.com/turkish-govt-toughens-kurdish-bid-stanceafter-attack-73495

International Committee of the Red Cross (ICRC). (2009). Water and War:The ICRC Response . www.icrc.org: https://www.icrc.org/eng/assets/files/other/icrc 002 0969.pdf

Keele, G. (2003, March 19). UNICEF, The Situation of Children in Iraq. www.unicef.org: https://www.unicef. $\mathrm{org} / \mathrm{media}$ media 7609.html

Koçer, G. (2005). Soğuk Savaş Sonrasında Uluslararası Güvenlik Ortamı ve Türkiye'nin Ulusal Güvenliği. Stratejik Araştırmalar Dergisi, 3(5), 287-304.

Lovelle, M. (2016). The Future Beyond Conflict: Food and Water Security in Syria. Future Directions International, http://www.futuredirections.org.au/publication/future-beyond-conflict-food-water-securitysyria/

Miles, T. (2015, December 01). U.N. condemns air strike that cut water supplies to Syria's Aleppo. Reuters: https://www.reuters.com/article/us-syria-crisis-aleppo-water-idUSKBN0TK4F020151201.

Mroue, B. (2012, November 26). Activists: Syrian rebels seize major dam in north. Associated Press: http:// www.dailystar.com.lb/News/Middle-East/2012/Nov-26/196180-activists-syrian-rebels-seize-major-damin-north.ashx 
Myers, N. (1993). Ultimate Security: The Environmental Basis of Political Stability. London: W. W. Norton \& Company. https://www.amazon.com/Ultimate-Security-Environmental-Political-Stability/dp/0393336212

O'Hara, G. (2017). The Politics of Water in Post-War Britain. London: Springer Nature.

Omara, J. O. (2017, February 03). Report: Water pipeline to ISIL stronghold Raqqa destroyed. November 22, 2019 tarihinde USA Today: https:/www.usatoday.com/story/news/world/2017/02/03/report-water-pipelineisil-stronghold-raqqa-destroyed/97436786/

Pacific Institute. (2021, March 16). Water Conflict Chronology. http://www.worldwater.org/: http://www. worldwater.org/conflict/map/

RAND Database of Worldwide Terrisom Incidents (RDWTI). (2019). National Security Research Division. www.rand.org: https://www.rand.org/nsrd/projects/terrorism-incidents/download.html.

Reznicck, A. (2016, January 04). Weaponizing Syria's Water. bostonreview: http://www.bostonreview.net/ world/syria-water-alisa-reznick

Schwartzstein, P. (2014, November 05). Amid Terror Attacks, Iraq Faces Water Crisis. National Geographic: https://www.nationalgeographic.com/science/article/141104-iraq-water-crisis-turkey-iran-isis

Sancak, K. (2013). Güvenlik Kavramı Etrafındaki Tartışmalar ve Uluslararası Güvenliğin Dönüşümü. Gümüşhane Üniversitesi Sosyal Bilimler Dergisi, http://acikerisim.ktu.edu.tr/jspui/handle/123456789/182 vol.6, 124-134.

Sancak, K. (2013). Güvenlik Kavramı Etrafındaki Tartışmalar Ve Uluslararası Güvenliğin Dönüşümü. Karadeniz Teknik Üniversitesi Sosyal Bilimler Dergisi(6), 124-134. http://www.ktu.edu.tr/dosyalar/sbedergisi_69519. pdf

Singer, D. (1971). A general systems taxonomy for political science. New York: General Learning Press .

Tawfeeq, M., \& Abdelaziz, S. (2016, November 30). ISIS uses water as weapon in Mosul fight. CNN World: https://edition.cnn.com/2016/11/30/middleeast/mosul-water-isis/

Terrorism Analysis Platform (TAP), 2021. Database of Terrorist Attacks, https://tap-data.com/analysis, accesed 18 March 2021.

The Armed Conflict Location \& Event Data Project (ACLED). (2019, November 21). Conflict analysis and crisis mapping. acleddata.com: https:/www.acleddata.com/data/

The Economist. (2019, November 18). Whatever happened to the water wars? economist.com: https://www. economist.com/graphic-detail/2019/11/18/whatever-happened-to-the-water-wars

The Global Terrorism Database (GTD). (2019, November). National Consortium for the Study of Terrorism and Responses to Terrorism (START). https://www.start.umd.edu/gtd/

The Jordan Times. (2015, August 23). PKK kills Turkish soldier, abducts customs officials army. jordantimes. com: $\quad$ http://www.jordantimes.com/news/region/pkk-kills-turkish-soldier-abducts-customs-officials$\% \mathrm{E} 2 \% 80 \% 94$-army

The Wilson Center. (2019, October 28). Timeline: the Rise, Spread, and Fall of the Islamic State. https://www. wilsoncenter.org/article/timeline-the-rise-spread-and-fall-the-islamic-state; Accesed date: 08.01.2020

Tierney, J., \& Worth, R. (2003, August 18). Attacks in Iraq Might Be Signs Of New Tactics. November 21, 2019 tarihinde New York Times: https://www.nytimes.com/2003/08/18/world/attacks-in-iraq-might-be-signs-ofnew-tactics.html

TRY World. (2017, March 08). Regime forces capture Aleppo's main water supply plant. November 22, 2019 tarihinde trtworld.com: https://www.trtworld.com/mea/regime-forces-capture-key-aleppo-water-supplyplant-312745

Ullman, R. H. (1983). Redefi ning Security. International Security, 8(01), 129-153.

UN Security Council. (2017, March 08). Physical Protection of Critical Infrastructure Against Terrorist Attacks. UN Counter-Terrorism Committee Executive Directorate (CTED): https://www.un.org/sc/ctc/news/ document/cted-trends-report-wednesday-8-march-2017-physical-protection-critical-infrastructure-terroristattacks/

US Agency for International Development. (2019, August 09). Syria - Complex Emergency. ReliefWeb.int: https://reliefweb.int/sites/reliefweb.int/files/resources/08.09.19\%20-\%20USG\%20Syria\%20Complex\%20 Emergency\%20Fact $\% 20$ Sheet $\% 20 \% 238$.pdf

Uzgel, İ., \& Bedirhanoğlu, N. (2016, Haziran). Eleștirel Bir Literatür Değerlendirmesi: Dışlamadan Sinırlı Tanımaya, Uluslararası İlișkiler Kuramları ve Marksizm. Uluslararası İlişkiler Dergisi, 12(46), s. 105-130. https://www.uidergisi.com.tr/wp-content/uploads/2016/06/46-6.pdf

Wolfers, A. (1952). National Security as an Ambigous Symbol. Political Science Quarterly, 67(4), 481-502.

Yanık, L. K. (2016, Hazşran). Liberalizm: Bir Yazın Değerlendirmesi. Uluslararası İlişkiler Dergisi, 12(46), s. 35-55. https://www.uidergisi.com.tr/wp-content/uploads/2016/06/46-3.pdf; Accesed date: 10.01.2020 
